\title{
Patiëntenvoorlichting
}

\section{PV 50. Osteosarcoom}

Een osteosarcoom is een kwaadaardig gezwel dat ontstaat vanuit het bot (= botkanker). Het gezwel kan op alle plaatsen in het skelet kan voorkomen en ook in het bot van onder- of bovenkaak. De oorzaak is onbekend. Botkanker kan soms al bij kinderen en jongvolwassenen voorkomen. De daarmee gepaarde klachten kunnen variëren van een niet pijnlijke zwelling tot los gaan staan van een of meer tanden en kiezen, of het gevoelloos raken van de onderlip aan de kant waar het gezwel zich bevindt.

De diagnose kan alleen worden vastgesteld aan de hand van weefselonderzoek. De behandeling van een osteosarcoom van de kaak bestaat uit chirurgische verwijdering, soms voorafgegaan en/of gevolgd door chemotherapie. Aangezien een osteosarcoom kan uitzaaien, wordt voorafgaand aan de behandeling nauwkeurig onderzoek naar eventuele uitzaaiingen (= metastasen) uitgevoerd.

Bij de operatieve verwijdering van een kaakosteosarcoom is het meestal onvermijdelijk om een deel van het kaakbot te verwijderen. In veel gevallen is het mogelijk om tijdens dezelfde operatie met een nieuw botstuk, weggenomen uit een andere plaats in het lichaam, bij voorbeeld het kuitbeen, het ontstane botdefect zo goed mogelijk te herstellen.

Wanneer er geen uitzaaiingen zijn en wanneer het is gelukt het gezwel voldoende ruim te verwijderen, zijn er goede kansen op volledige genezing.

\section{Wat kunt u zelf doen?}

Bij een osteosarcoom van het kaakbot kunt $U$ zelf niets doen. Wel is het belangrijk nog 5-10 jaar te laten controleren of de afwijking niet is teruggekomen of alsnog is uitgezaaid.
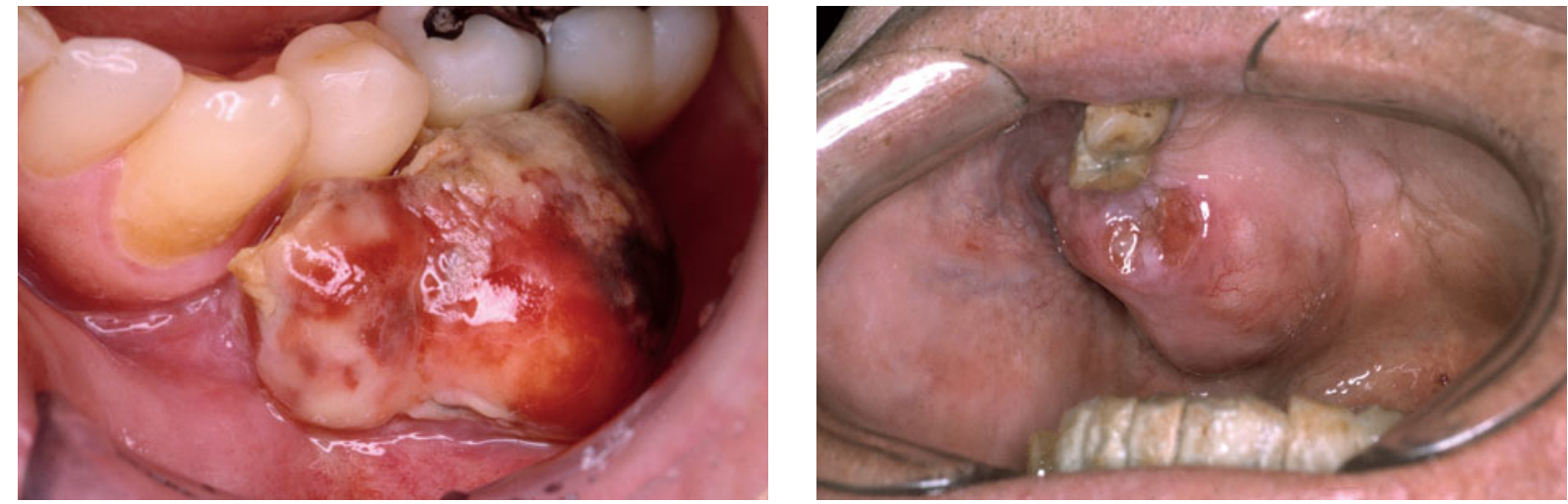